\title{
Development of Health Literacy for Regular Hemodialysis Patients in Menoufia Governorate: A Cross-Sectional Study
}

\author{
Said Sayed Ahmed Khamis', Mahmoud Mohammed Emara1, Marwa Salah Ahmed Elnashar2, \\ Muhammad Abdul Mabood Khalil ${ }^{3}$, Zeinab A. Kasemy 4
}

\begin{abstract}
${ }^{1}$ Department of Internal Medicine and Nephrology, Faculty of Medicine, Menoufia University, Shibin El Kom, Egypt ${ }^{2}$ Department of Internal Medicine and Nephrology, Teaching Hospital, Menoufia University, Shibin El Kom, Egypt ${ }^{3}$ Department of Renal Medicine, Consultant Nephrologist, RIPAS Hospital, Bandar Seri Begawan, Brunei Darussalam ${ }^{4}$ Department of Public Health and Community Medicine, Faculty of Medicine, Menoufia University, Shibin El Kom, Egypt Email: marwasalah123100@yahoo.com
\end{abstract}

How to cite this paper: Khamis, S.S.A., Emara, M.M., Elnashar, M.S.A., Khalil, M.A.M. and Kasemy, Z.A. (2021) Development of Health Literacy for Regular Hemodialysis Patients in Menoufia Governorate: A Cross-Sectional Study. Open Journal of Nephrology, 11, 199-216.

https://doi.org/10.4236/ojneph.2021.112016

Received: April 14, 2021

Accepted: May 21, 2021

Published: May 24, 2021

Copyright $\odot 2021$ by author(s) and Scientific Research Publishing Inc. This work is licensed under the Creative Commons Attribution International License (CC BY 4.0).

http://creativecommons.org/licenses/by/4.0/

\begin{abstract}
Health literacy (HL) is essential to access, comprehend, assess and use health data allowing patients to make better health and quality of life decisions. To assess the health literacy level of hemodialysis Egyptian patients, a cross-sectional study from March to September 2020 was conducted at 4 hemodialysis (HD) units on 439 patients. A translated questionnaire including demographic characteristics and health literacy components was conducted. This study adapted Nutbeam's model incorporating critical health literacy, interactive health literacy, and functional health literacy. Health literacy of hemodialysis patients was satisfactory among $35.5 \%$ of the studied patients. The average total score of health literacy questionnaire was $(15.53 \pm 4.32)$ distributed as $(2.90 \pm 1.26)$ for functional literacy, $(3.10 \pm 1.26)$ for basic health knowledge, $(1.65 \pm 1.21)$ for communicative literacy, $(2.53 \pm 0.70)$ for interactive literacy, $(1.75 \pm 1.30)$ for advanced health knowledge, $(1.74 \pm 0.48)$ for critical literacy, and $(1.83 \pm 0.93)$ for patient safety. It was found that poor health literacy was associated with low income ( $\mathrm{OR}=2.54$, CI 95\%: 1.66_3.89, $p<0.001$ ), of increasing age $(\mathrm{OR}=0.12 \mathrm{CI} 95 \%$ : 0.07_0.19, $p<0.001)$, low education $(\mathrm{OR}=$ 1.08, CI 95\%: 1.04_1.11, $p<0.001)$ and the patient did not undergo kidney transplant $\left(\mathrm{OR}=4.19 \mathrm{CI} 95 \%: 1.12 \_15.62, p=0.033\right)$. There was a prevalent low health literacy among the studied regular hemodialysis patients which was affected by education, age and income and in turn it affected the adherence to treatment. Understanding the linkage between HL and self-care attitudes should enhance efforts to improve hemodialysis outcomes.
\end{abstract}




\section{Keywords}

Limited Health Literacy among Dialysis Patients, Knowledge among Hemodialysis Patients, Regular Hemodialysis

\section{Introduction}

Dialysis has long been an important public health problem. Useful health outcomes and self-care abilities can be effectively achieved by raising the health literacy of hemodialysis patients.

Health literacy (HL) is essential to access, comprehend, assess and use health data allowing patients to make better decisions regarding their health and quality of life. Limited health literacy can hinder a patient's ability to interact with health services and social networks in the right way, negatively affecting their health outcomes [1].

Limited health literacy has been linked to low medication adherence, increased hospitalization, morbidity and mortality [2].

An appropriate HL enables renal patients to cope with a complex course of treatment with a heavy pill burden and required adherence to strong fluids and dietary restrictions. It can also be assumed that frequent and regular interactions with health systems and caregivers that are inherent in hemodialysis patient's treatment have the potential to enhance HL [3].

A validated Multidisciplinary Health Literacy Questionnaire (HLQ) has been used to assess several aspects related to a patient's interactivity with health systems and care delivery [4].

Based on our knowledge there is paucity of research about health literacy among hemodialysis Egyptian patients. This work aimed to assess the health literacy levels of hemodialysis Egyptian patients.

\section{Methods}

From March to September 2020, a cross-sectional study was performed at four Hemodialysis units at 4 different Egyptian districts. Adult patients who were receiving hemodialysis treatment for more than 3 months and who were able to communicate with their interlocutors were included in the study while those with a kidney transplant or were actively working for a living donor transplant, being diagnosed with dementia or mental impairment, had $<12$ months to live or were submitted to a course of renal palliative care were excluded.

A translated questionnaire (Appendix 1: English and Arabic forms) was adopted and it included questions about demographic characteristics and health literacy assessment:

- The demographic characteristics part included questions about patients' age, gender, education, income level and level of adherence to treatment.

- Assessment of health literacy: this study used the Nutbeam model and in- 
corporated the three main divisions; critical, inter-active and functional health literacy. The health literacy has seven sub-structures: functional literacy (5 components), communicative literacy (4 components), interactive literacy (3 components), critical literacy ( 3 items), basic health knowledge (4 components), advanced health knowledge ( 5 components) and patient safety (2 components). The correct answer took one point while the incorrect answer took zero. The final score ranged from 0 - 26 with at least $80 \%$ correct answers were taken as satisfactory HL.

The questionnaire items passed though several steps 1: Arabic translation by two bilingual translators; 2: the translators and two healthcare professionals discuss the inconsistencies in the translations; 3: two new translators translated the Arabic version of the questionnaire back to the original language for validity confirmation; 4: reviewing the final translations followed by developing the pre-final version of the questionnaire; 5: a pilot study on ten patients of various ages and education were applied to assess the degree of response, comprehension and reactivity.

Two days' workshop training and health education was delivered to a team of primary care physicians, and nurses to improve the accuracy of the results including discussion of the aim of this study, detailed explanations and descriptions of methods, and the overall intended contents. The whole team was tested to avoid inter and intra-observer bias. The surveys were delivered by interviewers on an individual basis to enhance the quality and the consistency of the contents. The interview was performed in the first hour of hemodialysis to avoid any potential fluctuations in cognitive function as a consequence of the hemodialysis process. To avoid patient fatigue, these interviews were performed in an interlocking fashion over successive hemodialysis sessions.

In-depth group educational sessions were conducted on how to deal with the disease, proper medication handling and its potential side effects, with an explanation of appropriate management, and how to manage daily activities after the hemodialysis session. Expansion of these health education sessions in addition to laboratory testing to include many other patients was recommended by all included patients.

\section{Sample Size}

The number of patients to be selected was estimated using the following equation: $n=\left(Z^{2} \times p \times q\right) / D^{2}$. Since the actual prevalence of health literacy was unknown, so yes equaled no ( $p=q=0.5, D=0.05)$. Based on these assumptions, 377 patients were required. Accounting for a dropout of $15 \%, 445$ patients were recruited. Out of 445 questionnaires distributed, 439 patients accepted to participate while 6 patients refused resulting in a response rate of $98.6 \%$.

\section{Statistical Analysis}

Analysis of data were performed using SPSS version 22.0 (SPSS Inc., Chicago, IL, 
USA). Data were presented as mean \pm SD or number and \%. Kruskal-Wallis test was used for comparison of more than 2 groups with non-parametric information while Mann-Whitney test was applied to compare between two groups. Spearman correlation was applied. Logistic regression was applied to detect the predictors of health literacy. Linear regression analysis for using pathway analysis was applied for scores of health literacy and ages and education level of the patients. A $p$-value was considered significant if $<0.05$.

\section{Results}

Patients' characteristics were illustrated in Table 1, kidney disease is mainly distributed among males by $57.6 \%$, those $>60$ years old by $40.8 \%$ and participants of low education by $85.6 \%$. Primary care-giving was mainly by self or spouse (58.5\%) followed by child or child spouse (35.1\%). Kidney transplant was reported among $10.3 \%$ of the studied participants (Table 1 ).

Health literacy was satisfactory among $35.5 \%$ of hemodialysis patients while it was unsatisfactory among $64.5 \%$ of them (Figure 1 ).

Table 1. Patients' characteristics.

\begin{tabular}{|c|c|c|}
\hline & $\mathrm{N}=43$ & $\%$ \\
\hline Age (Y) & & \\
\hline Mean \pm SD/Range & \multicolumn{2}{|c|}{$55.76 \pm 13.02 / 20-84$} \\
\hline \multicolumn{3}{|l|}{ Age (Y) } \\
\hline$\leq 50$ & 131 & 29.8 \\
\hline$>50-60$ & 129 & 29.4 \\
\hline$>60$ & 179 & 40.8 \\
\hline \multicolumn{3}{|l|}{ Sex } \\
\hline Male & 253 & 57.6 \\
\hline Female & 186 & 42.4 \\
\hline \multicolumn{3}{|l|}{ Education Level } \\
\hline Illiterate or primary school & 164 & 37.4 \\
\hline Preparatory school & 38 & 8.7 \\
\hline Secondary school & 174 & 39.6 \\
\hline College (and above) & 63 & 14.4 \\
\hline \multicolumn{3}{|l|}{ Income } \\
\hline Low & \multirow{2}{*}{$\begin{array}{l}331 \\
108\end{array}$} & 75.4 \\
\hline Moderate & & 24.6 \\
\hline \multicolumn{3}{|l|}{ Primary Caregiver } \\
\hline Self or spouse & 257 & 58.5 \\
\hline Child or child spouse & 154 & 35.1 \\
\hline Parents or siblings & 21 & 4.8 \\
\hline Others & 7 & 1.6 \\
\hline \multicolumn{3}{|l|}{ Kidney transplant } \\
\hline Yes & 45 & 10.3 \\
\hline No & 394 & 89.7 \\
\hline
\end{tabular}




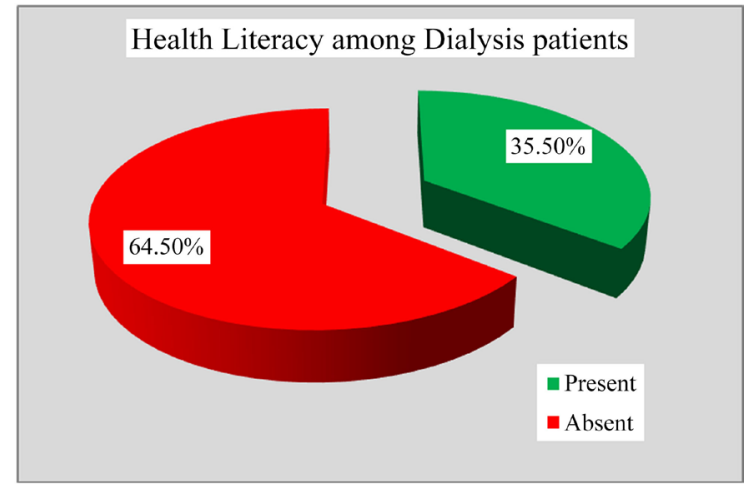

Figure 1. Health literacy among the studied participants.

The average total score of health literacy questionnaire was $(15.53 \pm 4.32)$ out of 26 possible criteria and it was distributed as $2.90 \pm 1.26$ for functional literacy, $3.10 \pm 1.26$ for basic health knowledge, $1.65 \pm 1.21$ for communicative literacy, $2.53 \pm 0.70$ for interactive literacy, $1.75 \pm 1.30$ for advanced health knowledge, $1.74 \pm 0.48$ for critical literacy, and $1.83 \pm 0.93$ for patient safety.

Among of these 7 sub-divisions, participants got high scores in basic functional literacy, health knowledge and interactive literacy but relatively low scores in advanced health knowledge, communicative literacy, critical literacy and patient satisfaction. Health literacy was high among young ages $<50$ years old $(17.94 \pm 3.46$ vs. $15.51 \pm 3.96$ and $13.75 \pm 4.32$ for $>50-60$ years old and $>60$ years old respectively), males (16.25 \pm 4.30 vs. females $14.54 \pm 4.19)$, moderate to high education $(18.58 \pm 2.70$ vs. $11.97 \pm 2.93$, when self or spouse was responsible for primary care-giving $(16.82 \pm 3.74$ vs. others $13.71 \pm 4.46)$ and those had kidney transplant $(20.37 \pm 2.19$ vs. no transplant $14.97 \pm 4.16)(P<0.001)$. Health literacy was high among those with moderate income in comparison to low income ones $(20.55 \pm 2.07$ vs. $13.89 \pm 3.53)$, also adherence to medication versus no adherence $(17.72 \pm 3.20$ vs. $12.91 \pm 4.02)(P<0.001)($ Table 2$)$.

A binary logistic regression was processed to highlight the responsible factors like age, gender, education, type of caregiver, and if the patient underwent kidney transplant for the liability that participants may have poor health literacy. For knowledge, the logistic regression sample was statistically significant, $\chi^{2}=$ 311.27, $p<0.001$. The model explained 69.8\% (Nagelkerke $R 2$ ) of the variance in poor health literacy and correctly classified $84.3 \%$ of cases. It was found that poor health literacy was associated with low income $(\mathrm{OR}=2.54, \mathrm{CI} 95 \%$ : $\left.1.66 \_3.89, p<0.001\right)$, of increasing age (OR $=0.12$ CI 95\%: 0.07_0.19, $\left.p<0.001\right)$, low education (OR $=1.08$, CI 95\%: $\left.1.04 \_1.11, p<0.001\right)$ and the patient did not undergo kidney transplant ( $\mathrm{OR}=4.19 \mathrm{CI} 95 \%$ : 1.12_15.62, $p=0.033$ ) (Table 3).

A significantly negative correlation was reported between age and the health literacy items $(P<0.05)$ while a significantly positive correlation was reported with the educational level $(P<0.05)$ (Table 4$)$.

Age and education are strong predictors to health literacy items especially advanced health knowledge where age $(\beta=-0.62$, CI 95\% $(-0.75)-(-0.48)$ and education ( $\beta=0.80$, CI 95\% 0.72_0.88) (Figure 2). 
Table 2. Demographic characteristics and health literacy of hemodialysis patients $(n=439)$.

\begin{tabular}{|c|c|c|c|c|c|c|c|c|}
\hline & $\begin{array}{c}\text { Functional } \\
\text { literacy }\end{array}$ & $\begin{array}{l}\text { Basic health } \\
\text { knowledge }\end{array}$ & $\begin{array}{c}\text { Communicative } \\
\text { literacy }\end{array}$ & $\begin{array}{c}\text { Interactive } \\
\text { literacy }\end{array}$ & $\begin{array}{l}\text { Advanced } \\
\text { health } \\
\text { Knowledge }\end{array}$ & $\begin{array}{l}\text { Critical } \\
\text { Literacy }\end{array}$ & Patient safety & Total \\
\hline \multicolumn{9}{|l|}{ Age (Y) } \\
\hline$\leq 50(\mathrm{n}=131)$ & $3.42 \pm 1.08$ & $3.34 \pm 0.62$ & $2.32 \pm 1.16$ & $2.74 \pm 0.56$ & $2.48 \pm 1.06$ & $1.70 \pm 0.50$ & $1.92 \pm 0.26$ & $17.94 \pm 3.46$ \\
\hline$>50-60(n=129)$ & $2.95 \pm 1.16$ & $3.11 \pm 0.64$ & $1.54 \pm 1.12$ & $2.52 \pm 0.67$ & $1.72 \pm 1.36$ & $1.79 \pm 0.42$ & $1.86 \pm 0.36$ & $15.51 \pm 3.96$ \\
\hline$>60(\mathrm{n}=179)$ & $2.48 \pm 1.30$ & $2.93 \pm 0.69$ & $1.25 \pm 1.12$ & $2.40 \pm 0.77$ & $1.23 \pm 1.18$ & $1.72 \pm 0.51$ & $1.74 \pm 0.46$ & $13.77 \pm 4.32$ \\
\hline$P$ value & $<0.001^{*}$ & $<0.001^{\star}$ & $<0.001^{*}$ & $<0.001^{*}$ & $<0.001^{*}$ & 0.251 & $<0.001^{*}$ & $<0.001^{*}$ \\
\hline \multicolumn{9}{|l|}{ Sex } \\
\hline Male $(\mathrm{n}=253)$ & $3.09 \pm 1.23$ & $3.13 \pm 0.69$ & $1.82 \pm 1.21$ & $2.56 \pm 0.67$ & $2.02 \pm 1.34$ & $1.77 \pm 0.48$ & $1.86 \pm 0.35$ & $16.26 \pm 4.28$ \\
\hline Female $(\mathrm{n}=186)$ & $2.64 \pm 1.25$ & $3.08 \pm 0.66$ & $1.43 \pm 1.18$ & $2.51 \pm 0.72$ & $1.38 \pm 1.16$ & $1.69 \pm 0.49$ & $1.79 \pm 0.43$ & $14.54 \pm 4.19$ \\
\hline$P$ value & $<0.001^{*}$ & 0.448 & $0.001^{*}$ & 0.456 & $<0.001^{*}$ & 0.128 & 0.053 & $<0.001^{*}$ \\
\hline \multicolumn{9}{|l|}{ Education Level } \\
\hline Low $(n=202)$ & $1.90 \pm 0.84$ & $2.72 \pm 0.60$ & $0.83 \pm 0.86$ & $2.28 \pm 0.80$ & $0.82 \pm 0.89$ & $1.71 \pm 0.48$ & $1.68 \pm 0.49$ & $11.97 \pm 2.93$ \\
\hline Moderate to high $(\mathrm{n}=237)$ & $3.75 \pm 0.86$ & $3.43 \pm 0.56$ & $2.37 \pm 1.0$ & $2.75 \pm 0.50$ & $2.54 \pm 1.06$ & $1.75 \pm 0.49$ & $1.95 \pm 0.20$ & $18.56 \pm 2.70$ \\
\hline$P$ value & $<0.001^{*}$ & $<0.001^{\star}$ & $<0.001^{*}$ & $<0.001^{*}$ & $<0.001^{*}$ & 0.373 & $<0.001^{*}$ & $<0.001^{\star}$ \\
\hline \multicolumn{9}{|l|}{ Income } \\
\hline Low & $2.45 \pm 1.07$ & $2.95 \pm 0.66$ & $1.26 \pm 1.02$ & $2.42 \pm 0.75$ & $1.32 \pm 1.06$ & $1.68 \pm 0.48$ & $1.77 \pm 0.43$ & $13.89 \pm 3.53$ \\
\hline Moderate + high & $4.27 \pm 0.66$ & $3.58 \pm 0.51$ & $2.85 \pm 0.96$ & $2.88 \pm 0.31$ & $3.05 \pm 1.10$ & $1.89 \pm 0.47$ & $2.0 \pm 0.0$ & $20.55 \pm 2.07$ \\
\hline$P$ value & $<0.001^{*}$ & $<0.001^{*}$ & $<0.001^{*}$ & $<0.001^{*}$ & $<0.001^{*}$ & 0.373 & $<0.001^{*}$ & $<0.001^{*}$ \\
\hline \multicolumn{9}{|l|}{ Primary Caregiver } \\
\hline Self or spouse $(n=257)$ & $3.21 \pm 1.09$ & $3.24 \pm 0.64$ & $1.90 \pm 1.18$ & $2.65 \pm 0.57$ & $2.19 \pm 1.24$ & $1.74 \pm 0.48$ & $1.88 \pm 0.32$ & $16.82 \pm 3.72$ \\
\hline Child or others $(\mathrm{n}=182)$ & $2.46 \pm 1.34$ & $2.92 \pm 0.69$ & $1.31 \pm 1.18$ & $2.37 \pm 0.82$ & $1.13 \pm 1.14$ & $1.73 \pm 0.49$ & $1.75 \pm 0.45$ & $13.71 \pm 4.46$ \\
\hline$P$ value & $<0.001^{*}$ & $<0.001^{*}$ & $<0.001^{*}$ & $<0.001^{*}$ & $<0.001^{*}$ & 0.884 & $0.001^{*}$ & $<0.001^{*}$ \\
\hline \multicolumn{9}{|l|}{ Kidney transplant } \\
\hline Yes $(\mathrm{n}=45)$ & $4.08 \pm 0.79$ & $3.57 \pm 0.46$ & $2.91 \pm 1.04$ & $2.84 \pm 0.36$ & $3.08 \pm 0.73$ & $1.86 \pm 0.45$ & $2.0 \pm 0.0$ & $20.37 \pm 2.19$ \\
\hline No $(\mathrm{n}=394)$ & $2.76 \pm 1.23$ & $3.05 \pm 0.68$ & $1.51 \pm 1.15$ & $2.50 \pm 0.72$ & $1.60 \pm 1.27$ & $1.72 \pm 0.49$ & $1.81 \pm 0.40$ & $14.97 \pm 4.16$ \\
\hline$P$ value & $<0.001^{*}$ & $<0.001^{*}$ & $<0.001^{*}$ & $<0.001^{*}$ & $<0.001^{*}$ & 0.057 & $<0.001^{*}$ & $<0.001^{*}$ \\
\hline \multicolumn{9}{|l|}{ Adherence to treatment } \\
\hline No $(n=200)$ & $2.21 \pm 1.18$ & $2.82 \pm 0.65$ & $1.04 \pm 1.07$ & $2.34 \pm 0.80$ & $0.99 \pm 1.08$ & $1.76 \pm 0.46$ & $1.72 \pm 0.46$ & $12.91 \pm 4.02$ \\
\hline Yes $(n=239)$ & $3.48 \pm 1.0$ & $3.34 \pm 0.61$ & $2.16 \pm 1.09$ & $2.70 \pm 0.54$ & $2.38 \pm 1.13$ & $1.71 \pm 0.50$ & $1.92 \pm 0.27$ & $17.72 \pm 3.20$ \\
\hline$P$ value & $<0.001^{*}$ & $<0.001^{*}$ & $<0.001^{*}$ & $<0.001^{*}$ & $<0.001^{*}$ & 0.168 & $<0.001^{*}$ & $<0.001^{*}$ \\
\hline
\end{tabular}

*: Significant.

Table 3. Predictors of limited health illiteracy among the studied patients.

\begin{tabular}{|c|c|c|c|c|}
\hline & \multirow{2}{*}{ OR } & \multicolumn{2}{|c|}{$95 \% \mathrm{CI}$} & \multirow{2}{*}{$P$ value } \\
\hline & & Lower & Upper & \\
\hline Age & 0.12 & 0.07 & 0.19 & $<0.001^{*}$ \\
\hline Sex (male) & 1.73 & 0.89 & 3.37 & 0.105 \\
\hline Education level (high) & 1.08 & 1.04 & 1.11 & $<0.001^{*}$ \\
\hline Income (high) & 2.54 & 1.66 & 3.89 & $<0.001^{*}$ \\
\hline Caregiver (self) & 1.31 & 0.74 & 2.33 & 0.346 \\
\hline Kidney transplant (yes) & 4.19 & 1.12 & 15.62 & $0.033^{\star}$ \\
\hline
\end{tabular}

\footnotetext{
*: significant (Reference).
} 
Table 4. Correlation between age and education level the patients and health literacy items.

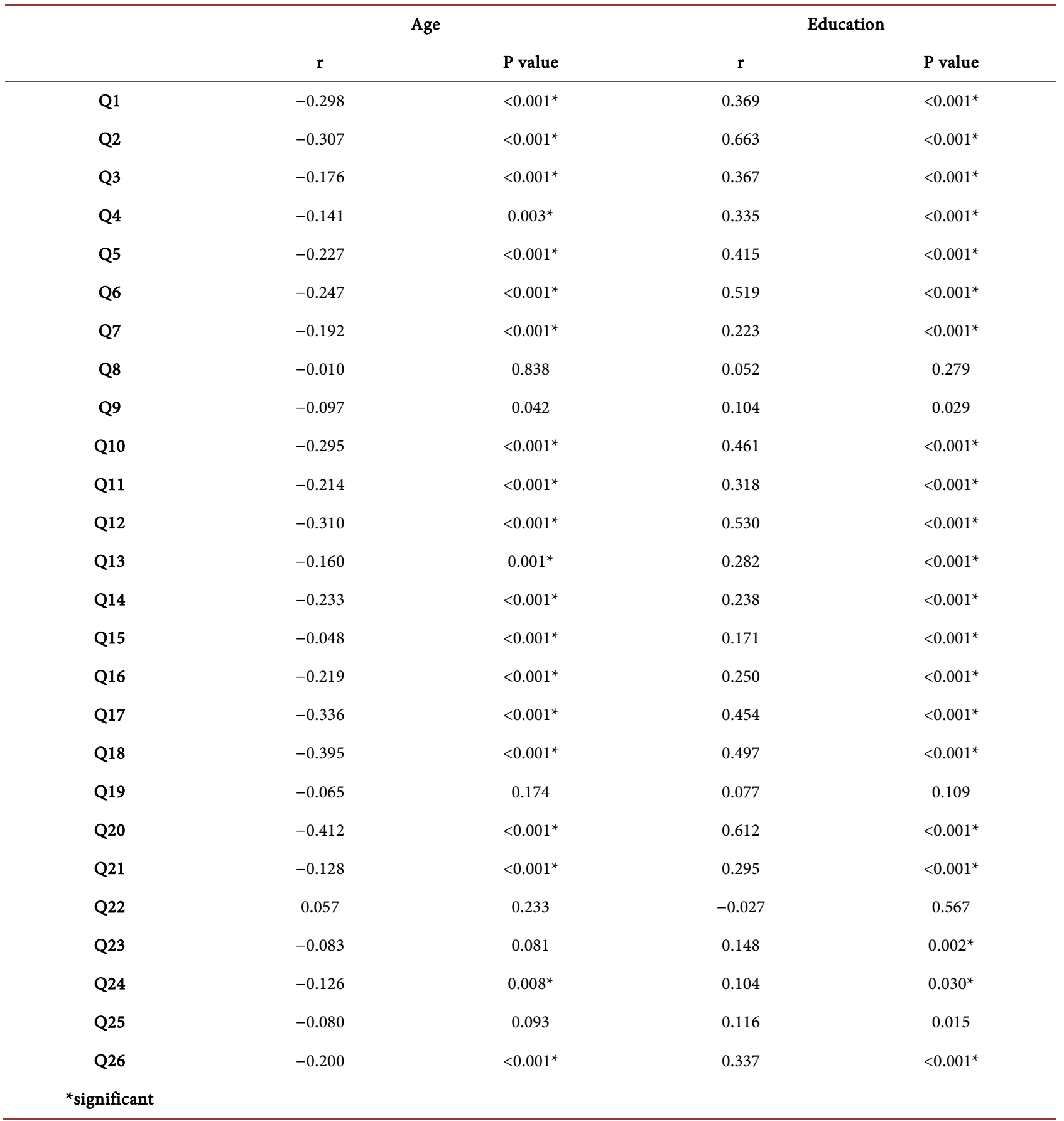

\section{Discussion}

Kidney disease was mainly reported among males (57.6\%), those $>60$ years old $(40.8 \%)$ and participants of low education (85.6\%). Primary care-giving was mainly by self or spouse (58.5\%) followed by a responsible child or child spouse (35.1\%). Kidney transplant was reported among $10.3 \%$ of the studied participants. These results were supported by Qobadi et al., [5] in Iran and Shih et al., [6] in Chinese Taipei. 


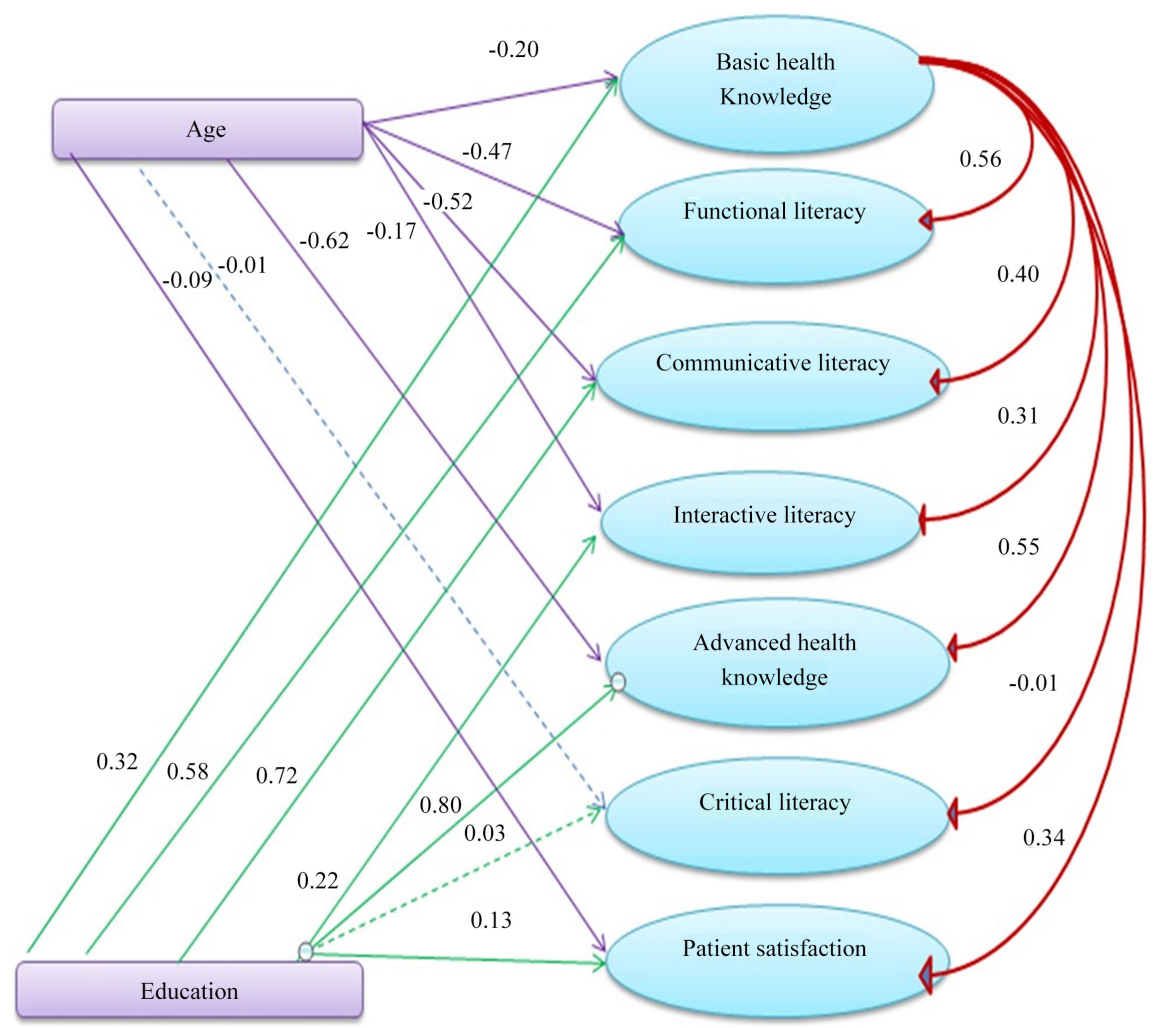

Figure 2. Path analysisof health literacy scores in relation to age and education level ( $\mathrm{n}=$ 439).

Health literacy of the current hemodialysis patients was satisfactory among $35.5 \%$ while unsatisfactory among $64.5 \%$ of them. This finding agrees with Qobadi et al., [5] in Iran who revealed that $65.2 \%$ his participants had considerable difficulty to understand and reading the information. On the contrary Green et al., [7] in USA, demonstrated a low HL in $16 \%$ of his patients. Murali et al., [8] in Australia, reported that limited HL ranges $8.4 \%-49.6 \%$ in ESKD patients versus $16.3 \%-63.3 \%$ in non-dialysis CKD patients. In the USA, Green et al., [9] found low HL ranging from $7 \%$ to $37 \%$ at the participating units of dialysis while Cavanaugh et al., [10] reported a Low HL up to $50 \%$.

This wide difference in the reported percentage of HL may be due to the different instruments used to measure HL or it may be a result of increased frequency of hospitalizations of dialysis patients, times of exposure to medical preparation per week in addition to their participation in educational programs or receiving health materials and also their repeated contact with the responsible health team in contrast to the normal population or other patients.

The average total score of HL questionnaire was $(15.53 \pm 4.32)$. The participants got high scores in basic functional literacy, basic health knowledge and interactive literacy but relatively low scores in the advanced health knowledge, communicative literacy, critical literacy and patient's satisfaction. HL was high among young ages $<50$ years old $(17.94 \pm 3.46)$ vs. $(15.51 \pm 3.96$ and $13.75 \pm$ 4.32) for those aged $>50-60$ years and $>60$ years respectively, males $(16.25 \pm$ 
4.30 vs. females $14.54 \pm 4.19)$, moderate to high education $(18.58 \pm 2.70$ vs. 11.97 $\pm 2.93)$, when self or spouse is responsible for primary care-giving $(16.82 \pm 3.74)$ vs. others $(13.71 \pm 4.46)$ and those have kidney transplant $(20.37 \pm 2.19)$ vs. no transplant $(14.97 \pm 4.16)$. All of these results agree with Shih et al., [6] in Chinese Taipei.

Health literacy was low among those with low income patients. These results agree with Cavanaugh et al., [11] in the USA and Grubbs et al., [12] in San Francisco who reported that lower income among participants, lower health literacy compared to higher health literacy. Grubbs et al., [12] found that HL scores were significantly lower among those > 65 years old and with incomes less than $\$ 30,000$ annually. Lee et al., [13] in the USA found that about $30 \%$ of adults were found to have low (inadequate or marginal) health literacy with lower household income. Lastrucci et al., [14] in Italy reported similar results (OR 2.03, 95\% CI: 1.28 - 3.21). In contrast, Mollakhaili, et al., [15] in Iran found that monthly income and education were not meaningfully related.

HL score was $(17.72 \pm 3.20)$ for those adherent to medication $(54.4 \%)$ versus non-adherent $(45.6 \%)(12.91 \pm 4.02)$. This result agrees with Cavanaugh et al., [11], Noureldin et al., [16] and Collins et al., [17] in the USA who reported also that prevalence of no adherence to medication in ESRD ranged from $22 \%$ to 74\%. In Australia, Ghimire et al., [18] found non-adherence among over 50\% of the dialysis patients. Low HL and hence low adherence is a direct cause of high mortality, increased utilization of health resources and poor quality of life of dialysis patients. Green et al., [7] patients with a low HL cannot read medication labels, medication instructions, and health brochures or better communicate and understand the health care staff which leads to taking inappropriate medications, discontinuing the prescribed diet, and selecting inappropriate treatment option.

The present finding revealed that low HL was significantly linked to the low educational level (OR = 1.08, CI 95\%: $1.04-1.11)$, increasing age (OR $=0.12 \mathrm{CI}$ 95\%: 0.07 - 0.19), and with kidney transplant (OR = 4.19 CI 95\%: 1.12 - 15.62). Paasche-Orlow et al., [19] in the USA reported high literacy among young ages $(\mathrm{OR}=15.9)$ comparing to low literacy among old ages $(\mathrm{OR}=37.9)$. Murali et al., [8] in Australia found that as age increased, there was "less capability to actively manage the health" (OR = 1.43). On the contrary Cavanaugh et al., [11] in the USA revealed no significant association between age, gender and race of the participants and HL.

Education is a strong predictor to health literacy items especially advanced health knowledge ( $\beta=0.62$, CI 95\% 0.72 - 0.88). Paasche-Orlow et al., [19] in USA, Lastrucci et al., (14) in Italy and Murali et al., [8] in Australia reported that the lower the educational level, the lower the rate of literacy (OR 2.59, 95\% CI: 1.66 - 4.02), in contrast Escobedo et al., [20] in the USA reported that assessment of educational level alone is not predictive of health literacy; (18\%) of participants had a high school or college education yet scored as having a limited health literacy.

Bains et al., [21] in the USA and Qobadi et al., [5] in Iran reported that low 
$\mathrm{HL}$ is a predictor of kidney knowledge. Lower disease-specific knowledge due to low literacy causes difficulty in understanding or reading disease specific medical information and management and low ability to communicate with medical staff.

Health literacy helps communication between patients, their caregivers, and health care providers to enhance the transmission, better understanding and useful application of information for successful health decision-making. In all patients whatever their conditions, a lower level of HL leads to less knowledge of one's health status, less participation in self-care especially when cognitive impairment is high in patients on dialysis and hence repeated hospitalization and death [22]. A broad understanding of these relationships will facilitate the development of targeted interventions to enhance health literacy, quality of care, and outcomes in renal patients. Designing appropriate educational interventions during the initial stages of CKD to prevent ESRD, increase the burden of renal failure and manage disease is essential.

\section{Strengths and Limitations}

The present work was carried out on Egyptian dialysis patients, thus generalization of the findings cannot necessary be achieved to all kidney patients in the world. Also, all data were self-reported with no gold standard for health literacy assessment, so this is a point of debate [23]. A post-test to assess HL post-health education was needed. But this work is the first to assess and investigate health literacy in a representative sample of patients on dialysis in Egypt. As noted $98.60 \%$ of the patients responded to the study which is so acceptable. This work included 439 participants providing statistically high power with consequently less Type 2 errors probability [24].

\section{Conclusion}

There was a prevalent low health literacy among the studied regular hemodialysis patients which was affected by education, age and income and in turn it affects the adherence to treatment. Understanding the linkage between HL and self-care attitudes should enhance efforts to improve hemodialysis outcomes.

\section{Acknowledgements}

The authors would like to thank all the participants for their time and kindness.

\section{Author Contribution}

All persons who meet authorship criteria are listed as authors, and all authors certify that they have participated sufficiently in this work. Said Sayed Ahmed Khamis, Muhammad Abdul Mabood Khalil and Mahmoud Mohammed Emara have the role of getting the idea and final revision, Zeinab A. Kasemy had the role of performing the statistical analysis, writing the methodology and results sections, final revision and publishing, Marwa Salah Ahmed Elnashar had the 
role of collecting the needed data and writing of the introduction and discussion.

\section{Data Availability}

All required data are included in the manuscript.

\section{Declarations}

\section{Ethics Approval and Consent to Participate}

This study was approved by the Committee for Medical Research Ethics at our Faculty of Medicine with ID: 191219INTM57.

\section{Informed Consent}

This study was obtained from all participants after explaining the main purpose of the research work. Consent for publication: The authors provide consent to publish.

\section{Disclaimer}

The authors are solely responsible for all contents.

\section{Conflicts of Interest}

The authors declare no conflicts of interest regarding the publication of this paper.

\section{References}

[1] Sørensen, K., Pelikan, J.M. and Röthlin, F. (2015) Health Literacy in Europe: Comparative Results of the European Health Literacy Survey (HLS-EU). European Journal of Public Health, 25, 1053-1058. https://doi.org/10.1093/eurpub/ckv043

[2] Taylor, D.M., Fraser, S. and Dudley, C. (2018) Health Literacy and Patient Outcomes in Chronic Kidney Disease: A Systematic Review. Nephrology Dialysis Transplantation, 33, 1545-1558. https://doi.org/10.1093/ndt/gfx293

[3] Murali, K.M., Mullan, J. and Roodenrys, S. (2019) Strategies to Improve Dietary, Fluid, Dialysis or Medication Adherence in Patients with End Stage Kidney Disease on Dialysis: A Systematic Review and Meta-Analysis of Randomized Intervention Trials. PLoS ONE, 14, e0211479. https://doi.org/10.1371/journal.pone.0211479

[4] Taylor, D.M., Fraser, S.D.S. and Bradley, J.A. (2017) A Systematic Review of the Prevalence and Associations of Limited Health Literacy in CKD. CJASN, 12, 1070-1084. https://doi.org/10.2215/CJN.12921216

[5] Qobadi, M., Besharat, M.A., Rostami, R. and Rahiminezhad, A. (2015) Health Literacy and Medical Adherence in Hemodialysis Patients: The Mediating Role of Disease-Specific Knowledge. Thrita, 4, e26195. https://doi.org/10.5812/thrita.26195

[6] Shih, C.L., Chang, T.H., Jensen, D.A. and Chiu, C.H. (2016) Development of a Health Literacy Questionnaire for Taiwanese Hemodialysis Patients. BMC Nephrology, 17, 12. https://doi.org/10.1186/s12882-016-0266-y

[7] Green, J.A., Mor, M.K., Shields, A.M., Sevick, M.A., Arnold, R.M., Palevsky, P.M., et al. (2013) Associations of Health Literacy with Dialysis Adherence and Health Resource Utilization in Patients Receiving Maintenance Hemodialysis. American Journal of Kidney Diseases, 62, 73-80. https://doi.org/10.1053/j.ajkd.2012.12.014 
[8] Murali, K., Mullan, J., Roodenrys, S. and Lonergan, M. (2020) Comparison of Health Literacy Profile of Patients with End-Stage Kidney Disease on Dialysis versus Non-Dialysis Chronic Kidney Disease and the Influencing Factors: A Cross-Sectional Study. BMJ Open, 10, e041404. https://doi.org/10.1136/bmjopen-2020-041404

[9] Green, J.A., Mor, M.K., Shields, A.M., Sevick, M.A., Palevsky, P.M., Fine, M.J., et al. (2011) Prevalence and Demographic and Clinical Associations of Health Literacy in Patients on Maintenance Hemodialysis. Clinical Journal of the American Society of Nephrology, 6, 1354-1360. https://doi.org/10.2215/CJN.09761110

[10] Cavanaugh, K.L., Wingard, R.L. and Hakim, R.M. (2010) Low Health Literacy Associates with Increased Mortality in ESRD. Journal of the American Society of Nephrology, 21, 1979-1985. https://doi.org/10.1681/ASN.2009111163

[11] Cavanaugh, K.L., Osborn, C.Y., Tentori, F., Rothman, R.L., Ikizler, T.A. and Wallston, K.A. (2015) Performance of a Brief Survey to Assess Health Literacy in Patients Receiving Hemodialysis. Clinical Kidney Journal, 8, 462-468. https://doi.org/10.1093/ckj/sfv037

[12] Grubbs, V., Gregorich, S.E., Perez-Stable, E.J. and Hsu, C.Y. (2009) Health Literacy and Access to Kidney Transplantation. Clinical Journal of the American Society of Nephrology, 4, Article ID: 195200. https://doi.org/10.2215/CJN.03290708

[13] Lee, S.Y.D., Tsai, T.I. and Tsai, Y.W. (2010) Health Literacy, Health Status, and Healthcare Utilization of Taiwanese Adults: Results from a National Survey. BMC Public Health, 10, 614. https://doi.org/10.1186/1471-2458-10-614

[14] Lastrucci, V., Lorini, C., Caini, S., Florence Health Literacy Research Group and Bonaccorsi, G. (2019) Health Literacy as a Mediator of the Relationship between Socioeconomic Status and Health: A Cross-Sectional Study in a Population-Based Sample in Florence. PLoS ONE, 14, e0227007. https://doi.org/10.1371/journal.pone.0227007

[15] Mollakhalili, H., Papi, A., Zare-Farashbandi, F., Sharifirad, G. and HasanZadeh, A. (2014) A Survey on Health Literacy of Inpatient's Educational Hospitals of Isfahan University of Medical Sciences in 2012. Journal of Education and Health Promotion, 3, 66 .

[16] Noureldin, M., Plake, K.S., Morrow, D.G., Tu, W., Wu, J. and Murray, M.D. (2012) Effect of Health Literacy on Drug Adherence in Patients with Heart Failure. Pharmacotherapy, 32, 819-826. https://doi.org/10.1002/j.1875-9114.2012.01109.x

[17] Collins, A.J., Foley, R.N., Herzog, C., Chavers, B., Gilbertson, D. and Ishani, A. (2009) United States Renal Data System 2008 Annual Data Report. The American Journal of Kidney Diseases, 53, S1-374. https://doi.org/10.1053/j.ajkd.2008.10.005

[18] Ghimire, S., Castelino, R.L., Jose, M.D. and Zaidi, S.T.R. (2017) Medication Adherence Perspectives in Haemodialysis Patients: A Qualitative Study. BMC Nephrology, 18, 167. https://doi.org/10.1186/s12882-017-0583-9

[19] Paasche-Orlow, M.K., Parker, R.M., Gazmararian, J.A., Nielsen-Bohlman, L.T. and Rudd, R.R. (2005) The Prevalence of Limited Health Literacy. Journal of General Internal Medicine, 20, 175-184. https://doi.org/10.1111/j.1525-1497.2005.40245.x

[20] Escobedo, W. and Weismuller, P. (2013) Assessing Health Literacy in Renal Failure and Kidney Transplant Patients. Progress in Transplantation, 23, 47-54. https://doi.org/10.7182/pit2013473

[21] Bains, S.S. and Egede, L.E. (2011) Associations between Health Literacy, Diabetes Knowledge, Self-Care Behaviors, and Glycemic Control in a Low Income Population with Type 2 Diabetes. Diabetes Technology \& Therapeutics, 13, 335-341. https://doi.org/10.1089/dia.2010.0160

[22] Wright, J.A., Wallston, K.A., Elasy, T.A., Ikizler, T.A. and Cavanaugh, K.L. (2011) 
Development and Results of a Kidney Disease Knowledge Survey Given to Patients with CKD. The American Journal of Kidney Diseases, 57, 387-395.

https://doi.org/10.1053/j.ajkd.2010.09.018

[23] Podsakoff, P.M., MacKenzie, S.B., Lee, J.Y. and Podsakoff, N.P. (2003) Common Method Biases in Behavioral Research: A Critical Review of the Literature and Recommended Remedies. Journal of Applied Psychology, 88, 879-903. https://doi.org/10.1037/0021-9010.88.5.879

[24] Cohen, J. (1988) Statistical Power Analysis for the Behavioral Sciences. Lawrence Erlbaum Associates Publishers, Hillsdale. 
Appendix 1. Health literacy in hemodialysis patients.

\section{Functional literacy:}

1. Which of the following statements is INCORRECT for patients who are receiving dialysis treatment?

A. They should consume a high-protein diet.

B. It is normal for their stool and urine to appear red.

C. They should consume plenty of red meat, which is rich in iron.

D. They should check their skin regularly for lesions or signs of infection.

2. Which of the following is NOT a purpose of dialysis?

A. To remove excess bodily fluid.

B. To filter out metabolic waste from the blood.

C. To improve the function of the GI system.

D. To balance the body's electrolytes.
14. What should you do when you receive treatment advice from non-medical sources?

A. Try it immediately.

B. Ask my nephrologist about it.

C. Ask other patients about it.

D. Ask my relatives about it.

15. What should you do when you have a GI problem?

A. Go to the hospital immediately and make sure to tell them that you're on dialysis.

B. Go to the hospital, but there is no need to mention that you're on dialysis.

C. Go to the hospital and only describe the GI problem.

D. Go to the pharmacy and buy OTC medication.

3. Which of the following statements regarding artificial blood vessel 16 . When receiving dialysis treatment, which of the following statements is (Port-A) or arteriovenous fistula care is TRUE? TRUE?

A. The patient can touch it or check with a stethoscope-it is functioning normally if it is silent.

B. The patient's blood pressure can be measured on the arm with the fistula.

C. A warm compress should be applied to the site of the fistula to induce blood circulation on the day of dialysis.

D. Redness at the site is normal and is no cause for concern.

4. Which of the following is a CORRECT way to control blood pressure?

A. Have a regular lifestyle and eat a low-sodium diet.

B. Stay up late working

C. Smoking tobacco and drinking.

D. The patient can adjust their dosage of medication depending on their current blood pressure.

5. Which of the following is NOT true for patients with uremia?

A. They can consume a high protein diet including foods like fish, pork, egg and milk.

B. They should not be concerned to find red spots in their stool.

C. They are advised to consume a high-iron diet rich in red meat.

D. They should regularly check their skin for abrasions and lesions.

\section{Basic Health Knowledge:}

6. Why do you need to control the intake of calcium, potassium and phosphorous?

A. Excessive intake can cause accumulation of these minerals in the body.

B. Uremia can decrease the density of bones, so it is important to replenish the body's stores of calcium.

C. These minerals are not important for human health.

D. The body cannot excrete these minerals normally due to decrease renal function.
A. When I feel better, I can decide to reduce the frequency of dialysis treatment on my own without my doctor's approval.

B. I should postpone all medication regimens until dialysis treatment finishes.

C. I should discuss any medications I'm taking with my nephrologist.

D. Feeling nauseated after dialysis is a normal symptom, and I do not need to tell the doctor.

\section{Advanced health knowledge:}

17. Which of the following is NOT a common complication in dialysis patients?

A. High blood pressure.

B. Cardiovascular disease.

C. Stroke.

D. Kidney stones.

18. Which of the following therapies can treat EndStage Renal Disease (ESRD)?

A. Traditional Chinese medicine and acupuncture.

B. Kidney transplantation.

C. Cocktail therapy.

D. Medication.

19. Which of the following statements about dialysis is FALSE?

A. Hemodialysis uses an artificial filter machine (artificial kidney) to filter excess fluid and waste products from the blood stream.

B. Peritoneal dialysis uses the patient's peritoneum (located in the abdomen) as a membrane across which excess fluids and waste products are exchanged from the blood.

C. Patients receiving hemodialysis need to visit a dialysis center 2 - 3 times a week to receive treatment.

D. Hemodialysis is more effective and has fewer complications than peritoneal dialysis. 


\section{Continued}

7. Which type of food should you AVOID when receiving dialysis?

A. Starfruit

B. Tofu

C. Fresh meat such as fish, duck, or chicken

D. Foods low in phosphorous and potassium

8. Which of the following is the medical reason for monitoring fluid intake?
20. Which of the following statements about kidney transplant is CORRECT?

A. I can only receive a kidney from blood relatives.

B. As long as someone is willing to donate their kidney, I don't need to wait and can proceed with transplantation immediately.

C. The condition of the donor and recipient must match in order for a transplantation to proceed.

A. There is calcium and potassium in water, which should be avoided. $\mathrm{D}$. Once the donor is willing to donate, there is no checkup needed.

B. Drinking enough water can help the kidneys get rid of excess

waste.

C. Water can cause edema inside the body due to decreased kidney function and urinary output.

D. Drinking too much water causes frequent bathroom visits.

9. Which of the following statements regarding fluid consumption is 21. Which of the following is an APPROPRIATE precaution when taking CORRECT for patients receiving dialysis? oral?

A. Measure out the daily fluid allowance and put it in bottles to be consumed throughout the day.

A. Before a dialysis session, I should stop taking all hypertensive medications.

B. It is fine to consume water-rich foods such as noodles, curry, and B. When I feel better, I can stop taking the oral medication. hotpot.

C. I don't need to take my medication on a regular schedule. I only need to

C. Fruit should be replaced with fresh juice. take it when I have elevated blood pressure.

D. The patient should eat more processed and heavily seasoned foods. D. Dialysis will remove the medication from my system, so I need to take oral medications again after the dialysis.

\section{Communication literacy:}

\section{Critical literacy}

10. What should you do when you are uncertain about medical advice 22. If your dry weight is $50 \mathrm{~kg}$, which of the following is NORMAL weight or a prescribed treatment regimen? gain?

A. Doctors are very intelligent and knowledgeable, so it's normal that A. 0 - $1 \mathrm{~kg} \mathrm{B.} 2$ - $3 \mathrm{~kg} \mathrm{C.} 4$ - $5 \mathrm{~kg}$ D. 5 - $6 \mathrm{~kg}$

I don't understand and I shouldn't ask for clarification.

B. It concerns my health; I have to find out the answer.

23. If the doctor tells you that you can gain $2 \mathrm{~kg}$ after two dialysis treatments, your urine output is about $200 \mathrm{cc}$, and you experience natural

C. I should ask my friends who have had similar problems. water loss of about $500 \mathrm{cc}$, what is your ideal amount of water intake per

D. It's just a minor issue, so I don't need to bother the doctor about it. ${ }^{\text {day? }}$

A. 700 cc B. 1700 cc C. 2700 cc D. 3700 cc

11. What should you do when you are uncertain about your prescribed medication?

A. I will not take any medication before asking my nephrologist.

B. I will take it first and monitor my condition.

C. These medications are normally safe, so it is okay to take them.

D. I need to take it because my doctor says it is necessary.

12. What should you do with your lab results?
24. Which of the following statements about self-care is CORRECT for patients receiving dialysis?

A. Patients should have a regular exercise schedule of at least 30 minutes 3 times a week.

B. I can consume traditional Chinese herbs to help with my disease.

C. I should use low-sodium salt when cooking.

D. Drinking a cup of wine can help with sleeping.

\section{Patient safety literacy :}

A. Lab results are too complicated, so I don't need to understand the 25 . Which of the following statements regarding fall prevention is TRUE? results as long as the doctor sees it.

A. After a dialysis treatment, even if I am feeling dizzy and nauseated I can B. I don't need to ask about my results because the doctors will tell meget off the bed without assistance. themselves.

C. I will ask about my results even if I don't understand everything.

D. Lab results are not important, so I won't ask about them.

B. I should gradually get off of the bed or change positions, and I can stand up only after I am able to sit up without experiencing dizziness.

C. Feeling dizzy is a normal and does not require extra precautions.

D. To prevent foot injuries, I can wear shoes that are larger than my regular size. 


\section{Continued}

13. What should you do if you feel uncomfortable or unwell after taking a prescribed medication?

A. I should contact my nephrologist immediately or go to the ER if can't reach my nephrologist.

B. I'm probably just overthinking things and there's no need to worry

C. I should stop taking the medication immediately, but there's no need to inform the doctor.

D. I should continue taking the medication because the doctor says I wound.

can't just stop whenever I want.

D. When there is redness or signs of swelling around the wound, I should go to the hospital immediately. If there is bleeding, I should not apply pressure to the wound.

Appendix 1. استبيان عن تتمية المعرفة الصحية لمرضي الغسيل الكلوي

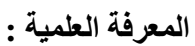

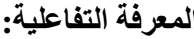

14. ماذا يجب أن تفعل عندما تتلقي نصيحة علاجية من مصادر غير طبية؟

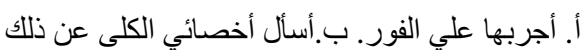

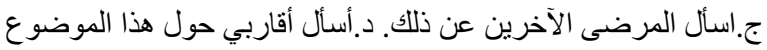

15. ماذا يجب أن تفعل عندما يكون لديكك مشكلة في الجهاز الهضمي؟

أ. أذهب إلي المستشفي علي الفور و التأكد من أخبار هم أنك تقوم بعمل غسيل الكلي .

ب. أذهب إلي المستشفي،لكن لا داعي لذكر أنك تقوم بغسيل الكلي .

ج. الذهاب إلي المستشفي ووصف فقط مشكلة الجهاز الهضمي .

د. الذهاب إلي الصبدلية وشر اء الأدوية اللاوصفية

16. عندما تتلقي علاج غسيل الكلي، أي من العبارات التالية صحيحة ؟

أ. عندما أشعر بالتحسن ،يمكنني أن أقرر تقليل نو اتر علاج غسيل الكلي لوحدى دون مو افقة طبيبي . ملون دون

ب. يجب علي تأجيل جميع أنظمة الدواء حتى ينتهي علاج غسيل الكلي .

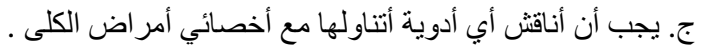

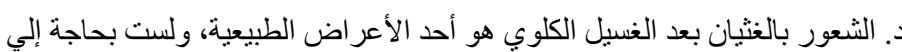
إخبار الطبيب

\section{المعرفة الصحية المتقدمة:}

17. أي مما يلي ليس شائع المضاعفات في مرضي غسيل الكلى؟

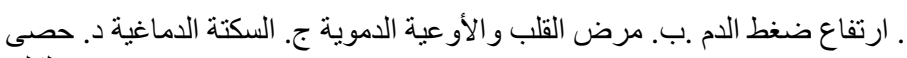
الكلى

18. أي من العلاجات التالية يمكن علاج المرحلة النهائية لمرض الكلي ؟

أ. الطب الصيني التقليدي والوخز بالإبر .ب. زرع الكلى .

ج. مزيج من العلاج .د. الدواء لباء
1- أي من العبارات التالية غير صحيح للمرضى الذين يتلقون علاج غسيل الكلي؟

أ. ينبغي عليهم أن يتناولو ا نظاما غذائيا عالي البروتين. ب. من الطبيعي البري

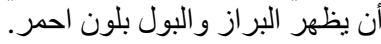

ج.ينبغي عليهم أن يستهكوا الكثير من اللحوم الحمر اء الغنية بالحديد.

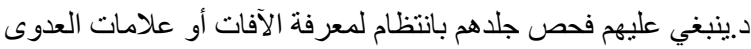

2- أي مما يلي ليس الغرض منه غسيل الكلي؟

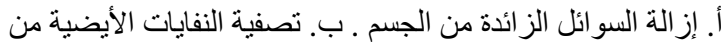

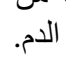

ج. تحسين وظيفة الجهاز الهضمي ـ د. تحقيق توازن الثو ارد في الجس

3- أي من العبارات التالية يعد صحيحا يتعلق بالأوعية الاصطناعية أو رعاية الناسور الشرياني الوريدى؟ بالاوئ الاصطئ

أ. يمكن للمريض لمسها أو التحقق منها من خلال سماعة الطبيب إنها

تعمل بشكل طبيعي إذا كانت خالية من الحركة (صامتة) .

ب. يمكن قياس ضغط دم المريض علي الذر اع عند الناسور.

ج. ينبغي الضغط علي نحو بسيط علي مكان الناسور للحث علي الدورز

الدموية في اي يوم عند القيام بغسيل الكلى. لإنى

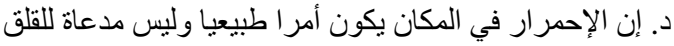

4. أي مما يلي يعد طريقة صحيحة للتحكم في ضغط الدم؟

أ. ينبغي أن يكون لديك أسلوب حياة منتظم و القيام بتناول النظام الغذائي

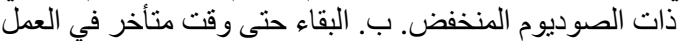

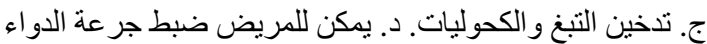

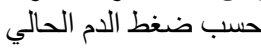

5. أي مما يلي صحيح بالنسبة للمرض الأين يعانون من تبلون الام؟

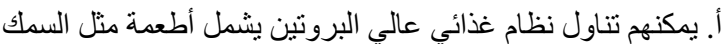
ولحم الخنزير و البيض والحليب.

ب. يجب ألا يبدوا إهتماما بإيجاد بقع حمر اء في البراز.

ج. ينصح بتناول نظام غذائي عالي الحديد غني باللحوم الحمر اء. لهائ. 
د.يجب عليهم فحص جلدهم بانتظام بحثا عن التآكل و الآفات

\section{المعرفة الصحية الأساسية : الماسية}

19. أي من العبار ات التالية خاطئة حول غسيل الكلى ؟

6. لماذا تحتاج للسيطرة على تناول الكالسيوم ، البوتاسيوم و

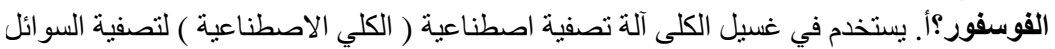

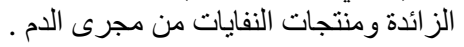

أ. يمكن للإفر اط في تناول الطعام أن يسبب تر اكم هذه المعادن في

الجسم. ب. يستخدم عندي مرضي غسيل الكلي الغشاء البريتونى (الموجود في البطن ) كغشاء

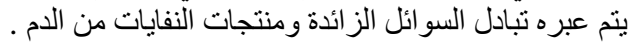

ب. يمكن لتبلون الدم ان يقلل من كثافة العظام ،لذلك من المهم تجديد

ج. يحتاج المرضي الذين ينلقون غسيل الكلي إلي زيارة غسيل الكلي2-3 مرات في في لئ

الأسبوع لتلقي العلاج .

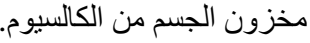

د. غسيل الكلي هو أكثر فاعلية ولها مضاعفات أقل من غسيل الكلي البريتوني

ج. هذه المعادن ليست مهمة لصحة الإنسان.

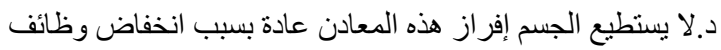
الكلي

20. أي من العبارات التالية عن زرع الكلى هي صحيحة؟

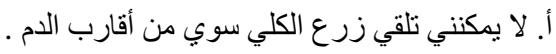

7- أي نوع من الطعام يجب أن تتجنبه عندما تقوم بعمل غسيل الكلي؟

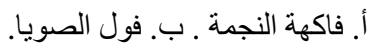

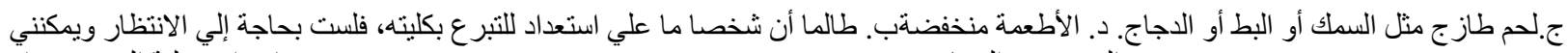

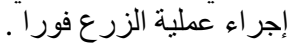

الفوسفور و البوثاسيوم

ج. يجب أن تتطابق حالة المتبرع و المتلقي حتى نتم عملية الزرع .

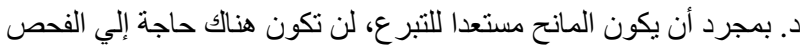

21. أي مما يلي يعد احتياطات مناسبة عند تناولها عن طريق الفم؟

أ. قبل جلسة غسيل الكلي ، يجب أن أتوقف عن تناول جميع الأدوية التي تسبب ارتفاع

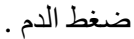

ب. عندما أ شعر بتحسن ، استطيع التوقف عن تناول الدواء عن طريق الفم .

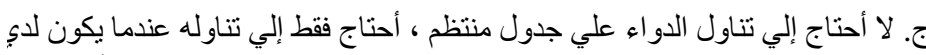

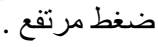

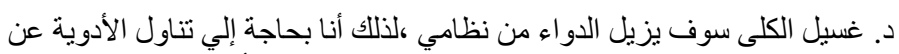

8- أي مما يلي هو السبب الطبي لمراقبة كمية السوائل؟

أ. هناك الكالسيوم و البوتاسيوم في الماء ،و التي ينبغي تجنبها.

ب. قد يساعد شرب كميه كافية من الماء الكلي علي التخلص من النفاياد الز ائدة.

جيمكن أن يسبب الماء تورم داخل الجسم بسبب انخفاض وظائف الكلي والإخر اج البولي.جي

ديسبب شرب الكثير من الماء زيار ات متكررة للحمام

طريق الفم مرة أخري بعد إلى غسيل الكلي

9- أي من العبارات التالية بخصوص استهلاك السوائل هو صحيح

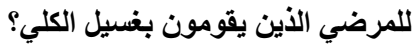

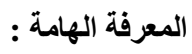

22. أذا كان وزنلك الجاف 50 كجم ، أبي مما يلي هو زيادة الوزن الطبيعي ؟

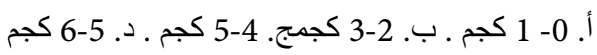

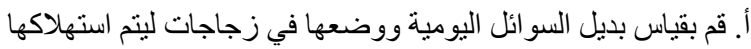

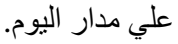

ب.من الأفضل أن تتناول الأطعمة الغنية بالمياه مثل المكرونة والكاري و الأطباق الساخنة.

ج. يجب استبدال الفاكهة بعصير طازج .د. يجب علي المريض تناول المزيد من الأطعمة المصنعة و المنبلة بكثرة

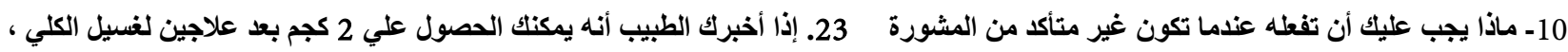

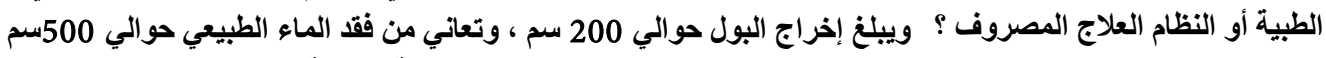

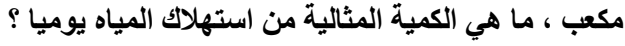

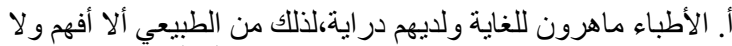

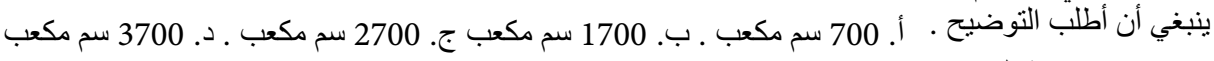

24. أي من العبارات التالية حول الرعاية الذاتية صحيحة للمرضى الذين يتلقون

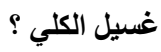

ب.إن الأمر يتعلق بصحتي،و لا بد من معرفة الجواب.

ج.يجب أن أسأل أصدقائي الذين لايهم مشاكل مماتلة.

أ. يجب أن يكون لدي المريض جدول منتظم لمدة 30 دقيقة علي الأقل 3 مرات في

د. إنها مجرد مشكلة بسيطة،لذلك لست بحاجة إلي إزعاج الطبيب حبال ذلك

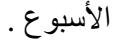

ب. يمكنتي تناول الأعثاب الصينية التقليدية للمساعدة في مرضي . 11. ماذا يجب أن تفعله عندما تكون غير متأكد من الأدوية

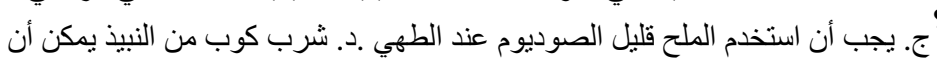
يساعد في النوم الموصوفة من الادوبه

أ. لن أنتاول أي دو اء قبل أن أسأل أخصائي الكلي . 
ب. سوف أتناولها أو لا وأراقب حالتي .

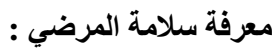

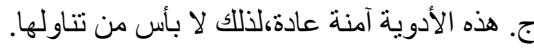

25. أي من العبارات التالية المتعلقة بمنع السقوط هي صحيحة ؟

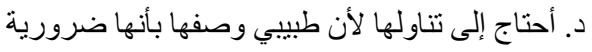

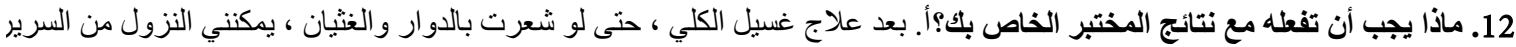

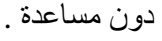

تر أبي الطبيب ذلك.ب. يجب أن اخرج تدريجيا من السرير ولا يمكنتي الوقوف إلا بعد أن أتمكن من الجلوسر

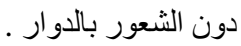

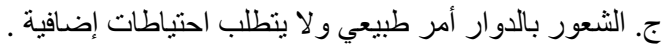

ب. لست بحاجة إلي السؤال عن نتائجي لأن الأطباء سيخبرونني

د. لهنع إصابات القدم ، يمكنني ارتداء أحذية أكبر من مقاسي المعتاد

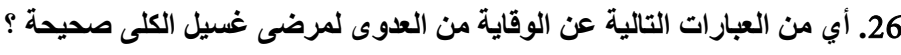

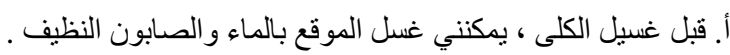
بأنفسهر.

ج. سوف أسأل عن نتائجي حتى لو لم أفهم كل شيء.د. نتائج المختبر ليست هامة، لذالك لن أسأل عنها

13. ماذا يجب أن تفعله إذا شعرت بعدم الارتياح أو بتو علك بعد تناول

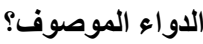

ب. بعد تركيب و عاء دموي اصطناعي ، يجب أن أحافظ علي نظافة الجرح ح.

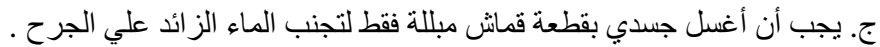

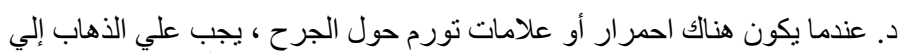

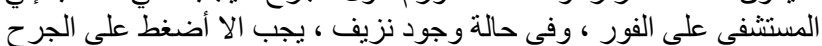

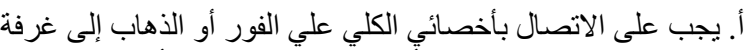

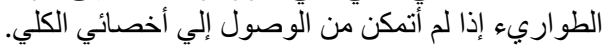

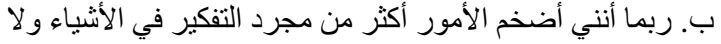

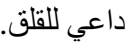

ج. يجب أن أتوقف عن تناول الدواء علي الفور ،لكن لا داعي لإبلاغ الطبيب.

د. يجب أن استمر في تناول الدواء لأن الطبيب يقول إنه لا يمكنني

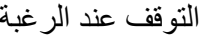

